Miami Nature Biotechnology Short Reports

TheScientificWorld (2001) 1(S3), 41SR

ISSN 1532-2246; DOI 10.1100/tsw.2001.148

\title{
ROLE OF STROMAL CELLS IN PROTECTING YOUNG AND AGED B-LINEAGE PRECURSORS FROM DEXAMETHASONE-INDUCED APOPTOSIS
}

\author{
Jeannette M. Pifer*, Robert P. Stephan, Deborah A. Lill-Elghanian, and Pamela L. Witte
}

Immunology and Aging Program, Loyola University Medical Center, 2160 S. $1^{\text {st }}$ Ave. Maywood, Illinois 60153, USA

* jpifer@lumc.edu

INTRODUCTION. B-lymphopoeisis is a balance between expansion and cell death. Bone marrow stromal cells support B-lymphopoeisis through direct cell-cell contact and by the production of growth factors, most notably IL-7, IGF-1, and SCF (1). Exposure to dexamethasone either in vivo or in vitro will cause the death of B-cells in early stages of development by inducing apoptosis. B-cell precursors appear to be protected from dexamethasone-induced apoptosis when co-cultured with the stromal cell line BMS2 (2). IL-7 is a possible anti-apoptotic factor since an increase in percentages of apoptotic B-cell precursors is seen in mice deficient in IL-7 production (3). However, even in IL-7 knockout mice, significant numbers of precursors still survive. Based on these findings, we hypothesized that IL-7 is the stromal derived mediator that protects B-cell precursors from dexamethasoneinduced apoptosis and the protective effects of IL-7 may be augmented by the growth factors IGF-1 and SCF. Furthermore, while IL-7 has been shown to induce proliferation in primary cultures of B-lymphocytes from young animals, this effect is not seen in primary cultures of Blymphocytes from aged animals. It is possible that, in aged animals, IL-7 acts to protect Blymphocytes from apoptosis in a manner similar to that observed with cells in young animals.

METHODS. B-lymphocytes, approximately 70\% pro-B cells, were harvested from Whitlocktype long-term bone marrow cultures from young (3mos) or old (22mos) BALB/c mice. Stromal cell lines were grown to $70 \%$ confluency before co-culture with pro-B cells. Cells were aliquotted into 24-well plates in $1 \mathrm{ml}$ volumes of $2.5 \times 10^{5}$ or $1 \mathrm{X} 10^{6}$ cells $/ \mathrm{ml}$. Dexamethasone was used at $10^{-6} \mathrm{M}$. IL-7 $(1.0 \mathrm{ng} / \mathrm{ml})$, IGF-1 and SCF $(50.0 \mathrm{ng} / \mathrm{ml})$ were added alone and in combination to samples that were incubated at $37 \mathrm{C}$ for the indicated time points. Cells were harvested from wells, washed for staining with Annexin V-FITC, or washed and fixed for staining with Propidium Iodide. Samples were analyzed by flow cytometry on a FACSCalibur using 488-nm excitation (575-nm emission) for PI and 488-nm excitation (525nm emission) for AV-FITC. IL-7 production by stromal cells was measured by bioassay.

RESULTS. Dex-induced apoptosis of B-cell precursors decreased in cultures containing the stromal cell lines tested regardless of levels of IL-7 production. rIL-7 and other factors produced by stromal cells were tested. Samples treated with IL-7 exhibited lower percentages of apoptosis than cells receiving no IL-7. SCF had very little effect in preventing apoptosis when administered alone or in combination with IL-7. IGF-1 alone offered protection to a lesser extent than IL-7 and the effects of these growth factors in combination was additive rather than synergistic. B-cell precursors from aged animals exhibited a slower rate of death than cells from young animals when treated with dexamethasone. Even though IL-7 failed to 
induce a proliferative response in cells from aged animals, preliminary evidence suggests that IL-7 may act to protect these cells from apoptosis.

DISCUSSION. B-lymphocytes from young and aged animals are protected from dexamethasone-induced death when cultured with stromal cells or stromal derived products. While IL-7 provides a high degree of protection, it is not the only factor capable of protecting B-lymphocytes from cell death. It is likely that IL-7 may act to influence the expression of either pro- or anti-apoptotic mediators such as bax or bcl-2 in a manner that correlates with protection against cell death.

ACKNOWLEDGEMENT. This work was supported by NIH Grant ROIAG13874 (to P.L.W.).

\section{REFERENCES.}

1. Gibson, L.F., Piktel, D., Narayann, R., Nunez, G., and Landreth, K.S. (1996) Exp. Hematol. 24, 628-637

2. $\quad$ Borghesi, L.A., Smithson, G., and Kincade, P.W. (1997) J. Immunol. 159, 4171-4179

3. Lu, L., Chaudhury, P., and Osmond, D.G. (1999) J. Immunol. 162, 1931-1940 

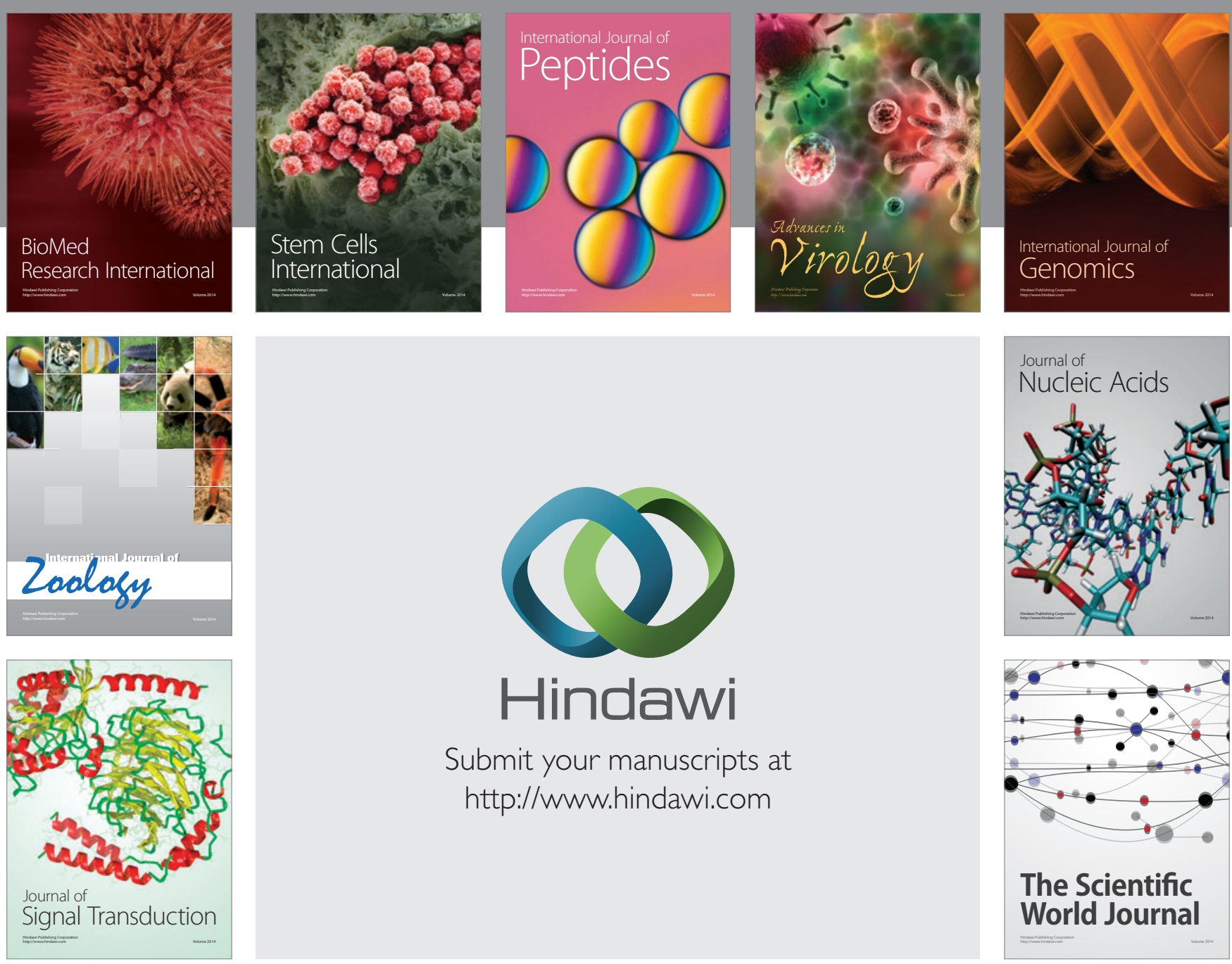

Submit your manuscripts at

http://www.hindawi.com
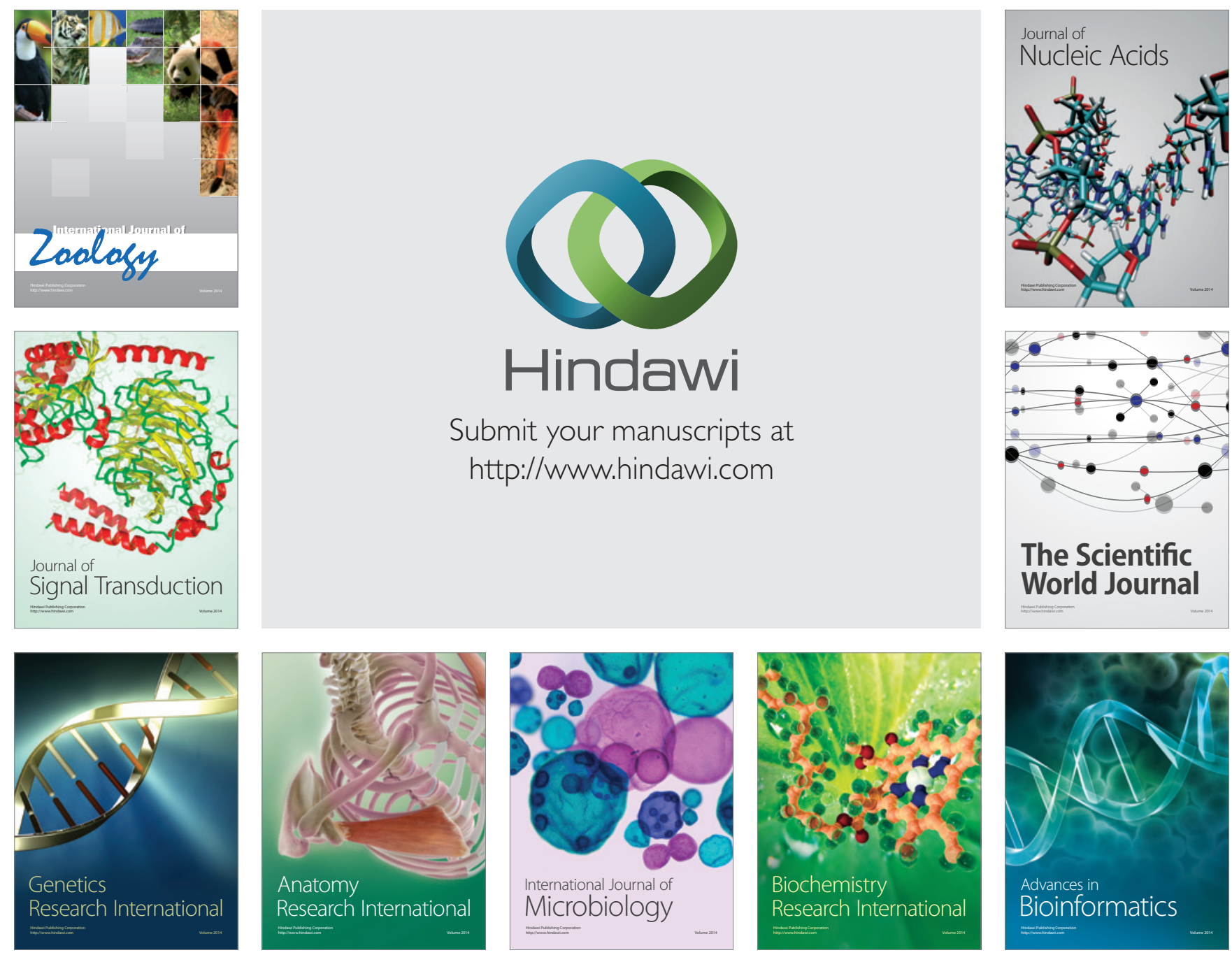

The Scientific World Journal
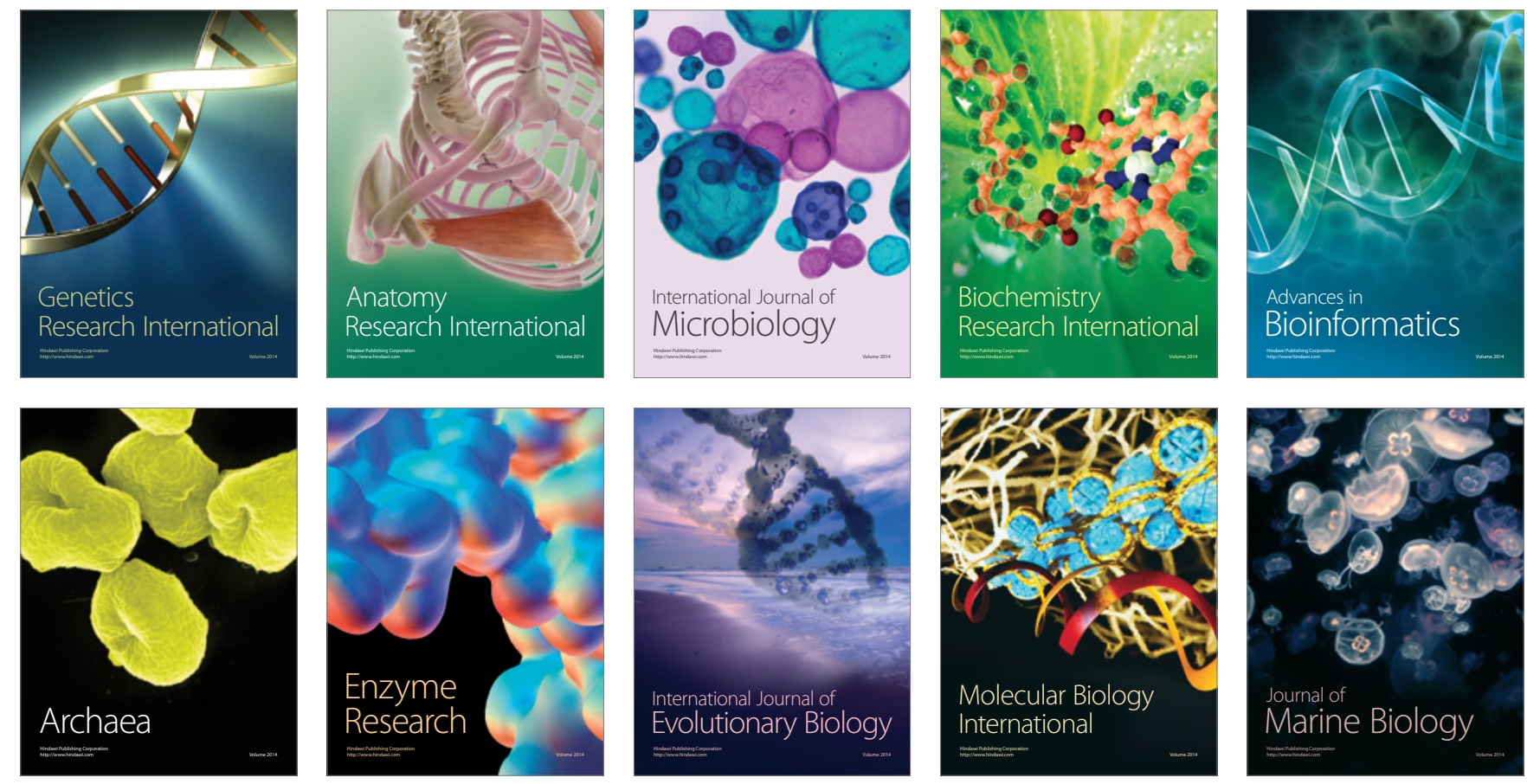